\title{
Lecturer passion: a pre-requisite for inspirational teaching
}

\author{
Robert Robson \\ University of Greenwich
}

\begin{abstract}
With reference to the ever-changing landscape within higher education $(\mathrm{HE})$ and the issue of marketplace differentiation, it has been suggested that universities need to prioritise the quality of the overall student experience, including the quality of classroom teaching (Holbeche 2012). Certainly, there exists a substantial body of literature relating to the theme of teaching effectiveness and - notwithstanding conflicting views, varying perspectives and the multi-dimensionality of the construct (Madriaga and Morley 2016) - it is evident that institutions of $\mathrm{HE}$ are attempting to address the upskilling of their lecturers through a blend of initiatives. Such initiatives include the provision of internal and external training courses, peer-review schemes and interventions by centralised educational development departments - for example, the provision of formal teaching qualifications such as a Postgraduate Certificate in Higher Education. In addition, some universities are holding learning and teaching festivals - events designed to provide a forum for discussion of topical learning and teaching themes and to enable the sharing of a range of good practice ideas.
\end{abstract}

These initiatives are important because a number of student-focused research studies have revealed that students in HE value teaching excellence, citing key qualities that they would like to see their lecturers display, such as enthusiastic delivery, capability, passion, dynamism and the ability to establish rapport (Heffernan et al., 2010; Kandiko and Mawer 2013; Bradley et al., 2015). In addition to the findings from research studies, universities have at their disposal institution-specific data relating to students' evaluation of teaching quality, of which some is anecdotal and some derived from more formal mechanisms, such as individual module evaluations and the National Student Survey. So then, a question arises: with a body of evidence available regarding the quality of teaching that students would like to experience, coupled with clear initiatives to improve the effectiveness of teaching within universities, why do survey results continue to reveal that student concerns over teaching quality persist?

I would argue that the true catalyst for transformational change is the passion for teaching which an individual lecturer personally feels. A lecturer's passion for teaching does not in itself equate to inspirational teaching delivery, but it is, arguably, the key driver for change. A lecturer with a genuine passion for teaching will be motivated, continually, to fine-tune and hone her/his craft and to seek to perfect the art of teaching. Without this passion, though lecturers may attend multifarious teacher-training programmes and undertake multiple peer observations, there is no guarantee, at the end of it all, that they will actively apply what they have learned. Interestingly, the findings of one research study into the willingness of lecturers to adopt new teaching methods revealed concerns over a lack of training in this area and a lack of self-confidence in the personal skills-set required (Bennett 2001). This is an important point. Lecturers with a passion for teaching may be more likely to adopt a more self-styled approach to their personal development and actively seek out ways of enhancing their learning over and above the training that the institution provides. In addition, if a lack of 
self-confidence is fed by a fear of the unknown, lecturers with a passion for teaching may possibly be more inclined to experiment and take risks because they have the desire to find out more about innovative teaching methods and 'lock down' new skills. It could be argued that most lecturers in HE have a passion for their subject; however, that passion may manifest itself primarily through dedication to research. I would argue that a passion for subject without a genuine passion for teaching is not enough to achieve inspirational teaching as judged by the student recipients. It should also be remembered that classroom teaching is only one facet - albeit an important one - of students' overall learning experience. Students may also value post-class support and dependable continuing opportunity for student/tutor interaction. Lecturers with a passion for teaching are well-placed to provide this because they will be driven not only by the satisfaction they derive from their classroom 'performance' that is the well-crafted mix of verbal exposition and other learning activities, but also by the eventual learning outcomes for the student. It is the passion for teaching that drives teaching excellence. This is critical, because, in the final analysis, the ability to inspire is the criterion against which lecturer performance will be judged.

\section{Reference list}

Bennett, R. (2001) Lecturers' attitudes towards new teaching methods. The International Journal of Management Education. 2 (1), 42-58.

Bradley, S., Kirby, E. and Madriaga, M. (2015) What students value as inspirational and transformative teaching. Innovations in Education and Teaching International. 52 (3), 231242. doi: $10.1080 / 14703297.2014 .880363$.

Heffernan, T., Morrison, M., Sweeney, A. and Jarratt, D. (2010) Personal attributes of effective lecturers: the importance of dynamism, communication, rapport and applied knowledge. International Journal of Management Education. 8 (3), 13-27. doi: 10.3794/ijme.83.275.

Holbeche, L. (2012) Changing times in UK universities: what difference can HR make? Loughborough, Universities Human Resources. [Available at: docplayer.net/3165158Changing-times-in-uk-universities-what-difference-can-hr-make.html (Accessed: 29 October 2019).

Kandiko, C. B. and Mawer, M. (2013) Student expectations and perceptions of higher education. London, King's Learning Institute. [Available at: https://www.kcl.ac.uk/study/learningteaching/kli/People/Research/DL/QAAReport.pdf (Accessed: 29 October 2019).

Madriaga, M. and Morley, K. (2016) Awarding teaching excellence: 'what is it supposed to achieve?' Teacher perceptions of student-led awards. Teaching in Higher Education. 21 (2), 166-174. doi: 10.1080/13562517.2015.1136277. 